は, 各組成域での未端 $\mathrm{OH}$ 基，または中間 $\mathrm{OH}$ 基の脱 出によって生ずべき鎖状燐酸塩の鎖長または分岐構造に おける分岐点数の増大によって説明される.また，分子 屈折の増大は, 水素イオンのためにその電子雲をひきし められていた隣接酸素原子が， $\mathrm{OH}$ 群の脱出とともにそ の分極性を回復することによると説明される。

（5）水分の減少に伴う密度および屈折率の減少は, 一応, 構造的に体積増加をもたらす結果として理解され るが, anomalous glass に属する $\mathrm{MgO}$ - および $\mathrm{ZnO}$ $\mathrm{P}_{2} \mathrm{O}_{5}$ 系ガラスの場合, 中間 $\mathrm{OH}$ 基の脱出が起らざるを 得ないような組成的条件の下では，膨脹よりもむしろ構 造収縮が起きるといら特異性が認められた。

(6) $\mathrm{H}_{2} \mathrm{O} / \mathrm{P}_{2} \mathrm{O}_{5}$ 比を一定にそろえた系列試料につい て，その密度と屈折率を $\mathrm{R}_{\mathrm{MH}}$ に対してプロットして得 られる曲線では， $R_{\mathrm{MH}}=1$ の組成において， $\mathrm{MgO}$ $\mathrm{P}_{2} \mathrm{O}_{5}$ 系ガラスははげしい不連続的急変をみせ， $\mathrm{CaO}-$ および $\mathrm{CdO}-\mathrm{P}_{2} \mathrm{O}_{5}$ 系ガラスでは単なる屈曲点を生じた， この現象によっても, 含水燐酸塩ガラスの組成変動に伴 う構造変換に対しては, $\mathrm{H}_{2} \mathrm{O}$ をも考慮に入れた $R_{\mathrm{MH}}$ が 決定的な組成パラメーターとなることが明らかになっ た.

本研究における燐酸塩中の水分の定量法について有益な御教 示を頂いた工業技術院電気試験所亚河洋氏に対して深甚なる謝 意を表します。

\section{文献}

1) H.Salmang and A. Becker, Glastech. Ber. 5, 520 (1928); ibid. 6, 625 (1929); ibid. 7, 241 (1930).

2) R.H. Dalton, J. Am. Ceram. Soc. 16, 425 (1933); J. Am. Chem. Soc. 57, 2150 (1935).

3) A.J. Harrison, J. Am. Ceram. Soc. 30, 362 (1947).

4) J.M. Florence et. al., J. Am. Ceram. Soc. 31, 328 (1948); J. Res. Nat. Bur. Stand. 45, 121 (1950); ibid. 50, 187 (1953).

5) H. Scholze, Glastech. Ber. 32, 81, 142, 278, 314 (1959); H. Scholze and H.O. Mulfinger, ibid. 32, 381 (1959); H. Scholze, H. Franz, and L. Merker, ibid. 32, 421 (1959); R. Brückner, ibid. 38 [4] 153 (1965).

6) R.V. Adams, Phys. and Chem. Glasses 2 [2] 39 (1961).

7) G. Hetherington and K.H. Jack, ibid. 3 [4] 129 (1962).

8) J.L. Passons and M.E. Milberg, J. Am. Ceram. Soc. 43 [6] 326 (1960).

9) F. Meller and M.E. Milberg, ibid. 43 [7] 353(1960).

10) F.C. Eversteijn, J.M. Stevels, and H.I. Waterman. Phys. and Chem. Glasses 1 [4] 123 (1960).

11) W. Poch, Glastech. Ber. 37 [12] 533 (1964).

12) H. Franz, ibid. 38 [2] 54 (1965).

13）並河 洋, 宗像元介, 窯協誌, 73 [2] 86 (1965).

14）並河 洋, 浅原慶之, ibid. 74 [6] 205 (1966).

15）成瀬 省, 阿部良弘, 名工大窯研報告, 1, 1 (1963).

16）成瀬 省, 阿部良弘, ibid. 3,1 (1966).

17) E. Kordes, W. Vogel, and P. Feterowsky, Z. Elektrochem. 57 [4] 282 (1953); E. Kordes and H. Becker, Z. anorg. Chem. 260 [4] 185 (1949).

18) C.A. Elyard, P.L. Baynton. and H. Rawson, Glastech. Ber. Sonderband, 32 K VI 36 (1959).

19) K. Takahashi, Advances in Glass Technology(Technical Papers of the VIth I.C.G.) 366 (1962).

20) E.J Griffith and C.F. Callis, J. Am. Chem. Soc. 81 833 (1959).

21) J.R. Van Wazer, Phosphorus and Its Compounds, Vol. 1, 706 716 (1958), Interscience Pub. Inc., New York.

22) D.E.C. Corbridge and E.J. Lowe, J. Chem. Soc. 493 (1954); ibid. 4555 (1954).

23) D.J. Williams, B.T. Bradbury, and W.R. Maddocks, J. Soc. Glass Tech. 43,337 T (1959).

24) W.A. Weyl and E.C. Marboe,The Constitution of Glasses, Vol. 2 Part 1, 582 (1964).

(6/26/1967 受付)

\title{
7. Presence of Syngenite in Commercial Portland Cement
}

\author{
By \\ Kinjiro FUJII, Wakichi KONDO and Norio MASIMO \\ (Government Chemical Industrial Research Institute, Tokyo)
}

\section{Introduction}

The commercial portland cement usually contains a few percent of non-evaporable water and on the amount of which the limitation has been imposed according to JIS-R 5210 not to exceed four weight percent as a weight loss by ignition. The main source of such non-evaporable water may be ascribed to gypsum which was added to cooled clinker in a mill, the combined water thereof however, might be released from by the heat generated through ball milling and recombine to form any other hydrate than gypsum. The present work was undertaken in the hope of obtaining the information about the species and quantities of the hydrates present in commercial portland cement.

\section{Experimental}

2.1. Samples of portland cements and clinkers 
Table 1. Chemical analysis of portland cements and clinkers (wt. \%).

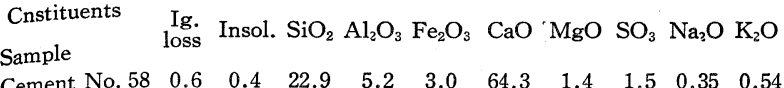

$\begin{array}{rllllllllll}\text { Cement No. } 58 & 0.6 & 0.4 & 22.9 & 5.2 & 3.0 & 64.3 & 1.4 & 1.5 & 0.35 & 0.54 \\ 59 & 0.6 & 0.5_{5} & 22.1 & 5.0 & 3.1 & 65.1 & 1.6 & 1.7 & 0.17 & 0.26\end{array}$

$\begin{array}{lllllllllll}60 & 0.7 & 0.5 & 21.8 & 5.1 & 3.0 & 65.3 & 1.2 & 1.7 & 0.24 & 0.51\end{array}$

$\begin{array}{lllllllllll}61 & 0.9 & 0.7_{5} & 22.4 & 4.9 & 2.9 & 64.3 & 1.1 & 2.0 & 0.33 & 0.46\end{array}$

$\begin{array}{lllllllllll}62 & 0.6 & 0.9 & 22.0 & 5.3 & 3.0 & 64.5 & 1.5 & 1.5 & 0.44 & 0.33\end{array}$

$\begin{array}{lllllllllll}63 & 1.0 & 0.1 & 21.9 & 5.1 & 3.1 & 64.4 & 1.7 & 1.6 & 0.45 & 0.59\end{array}$

$\begin{array}{lllllllllll}64 & 0.4 & 0.8 & 21.3 & 5.2 & 3.2 & 64.7 & 1.4 & 2.2 & 0.25 & 0.61\end{array}$

$\begin{array}{lllllllllll}65 & 0.4 & 0.5 & 22.8 & 4.9 & 3.1 & 64.6 & 1.6 & 1.4 & 0.39 & 0.51\end{array}$

$\begin{array}{lllllllllll}66 & 0.8 & 0.9 & 22.2 & 5.1 & 3.1 & 63.6 & 1.4 & 1.9 & 0.50 & 0.68\end{array}$

$\begin{array}{lllllllllll}01 & 0.8_{5} & 0.8 & 22.1 & 5.4 & 3.1 & 63.6 & 1.4 & 2.0 & 0.36 & 0.72\end{array}$

$\begin{array}{lllllllllll}02 & 0.8_{3} & 0.7 & 23.6 & 4.1 & 4.0 & 63.4 & 1.1 & 1.8 & 0.10 & 0.38\end{array}$

$\begin{array}{lllllllllll}03 & 0.7_{5} & 0.8 & 21.1 & 4.7 & 2.7 & 65.5 & 1.5 & 2.5 & 0.21 & 0.47\end{array}$

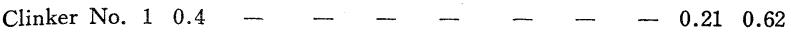

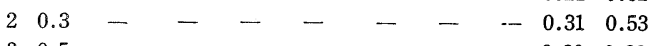

$30.5-\quad-\quad-\quad-\quad-\quad-0.200 .32$

In the present work twelve samples of commercial portand cements and three of clinkers were used. The results of chemical analysis for them are shown in Table 1.

\subsection{Chemical analysis}

The methods for chemical analysis of portland cement and chinker are described in JIS-R 52021962. The content of free lime was determined by the modified alcohol-glycerol method recommended by The Cement Association of Japan.

\subsection{Differential thermal analysis}

The arrangement for differential thermal analysis (DTA) is illustrated in Figure 1 with sample and reference standard $\left(\mathrm{Al}_{2} \mathrm{O}_{3}\right)$ placed in holes drilled in a ceramic holder. The thermocouple of ChromelAlumel $(0.15 \mathrm{~mm} \phi)$ was directly placed in the sample and reference, and the e.m.f. developed was amplified and recorded at a full scale of 250 $\mu$ volt. A heating rate of $10^{\circ} \mathrm{C} / \mathrm{min}$. was used.

The main hydrates in commercial portland cement, which are present enough to bring forth an endothermic peak in DTA curves, are gypsum, syngenite and calcium hydroxide. For quantitative estimations of these hydrates, the apparatus must be calibrated by observing the peak area corresponding to the thermal effect of respective mateials, the known amount of which being incorporated in a diluent ${ }^{1)}$. As a diluent, the clinker No. 2 was used to make the calibration curve for gypsum and syngenite, and the cement No. 64 for calcium hydroxide. The calibration curves thus obtained were shown in Figure 2, in which almost straight-line co-relations between peak areas and the contents of the materials mentioned could be established. From the points used to establish Figure 2, one should be able to determine upto about $10 \mathrm{mg}$ of each hydrate (that is, $2 \mathrm{wt} . \%$ for the sample size of $500 \mathrm{mg}$ ) within a probable error of $\pm 0.5 \mathrm{mg}$ of each hydrate.

2.4. Determination of moisture content by use of Karl Fischer reagent

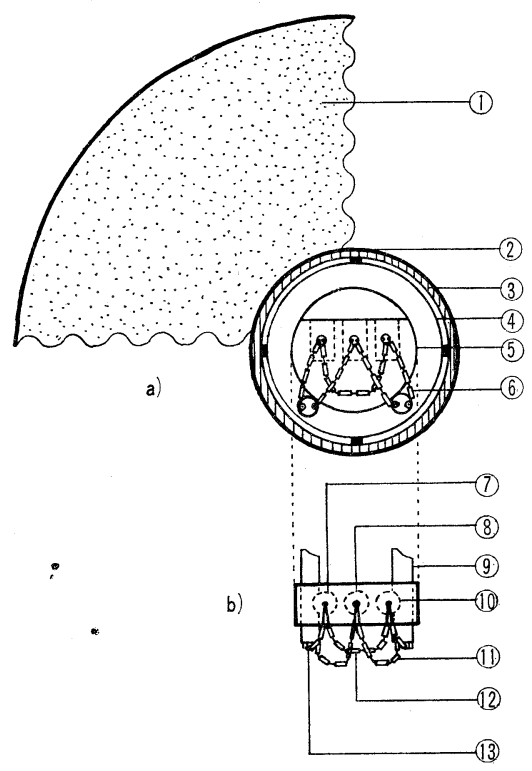

a) cross sectional view

b) top view of ceramic holder

(1) thermal insulator

(2) Kanthal winding

(3) silica glass tube

(4) radiation shield(steel tube)

(5) ceramic holder (alumina block, $33 \mathrm{~mm} \phi \times 13 \mathrm{~mm}$ )

(6) electric insulator tube

(7) reference standard, $\alpha$ $\mathrm{Al}_{2} \mathrm{O}_{3}$ powder

(8) hole for inserting thermocouple $(6 \mathrm{~mm} \phi \times 13 \mathrm{~mm})$

(9) silica glass tube $(7 \mathrm{~mm} \phi)$

(10) sample

(11) Pt-PtRd thermocouple

(12) Alumel wire

(13) chromel wire (the ends of both wires are directly placed in holes)

Fig. 1. The apparatus used for DTA.

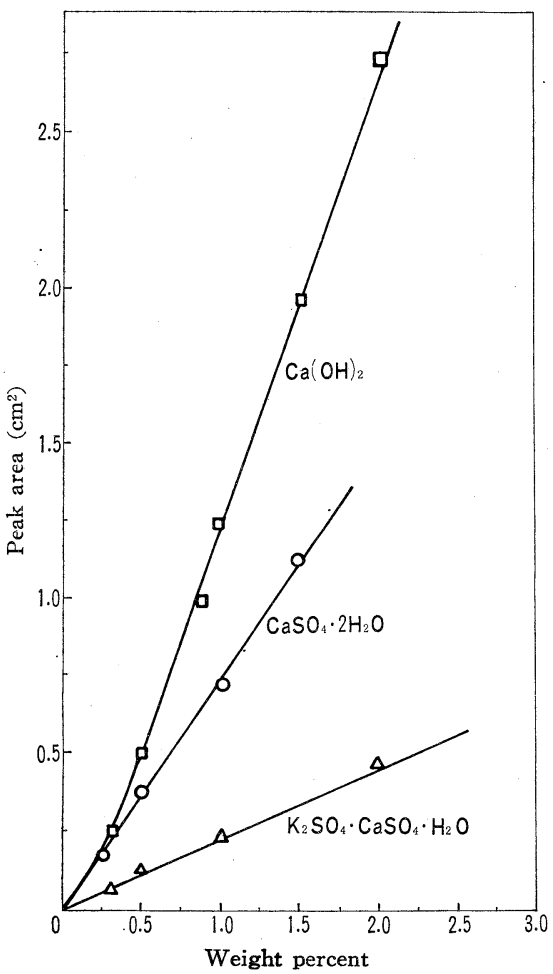

Fig. 2. Calibration curves for DTA of gypsum, syngenite and calcium hydroxide. 


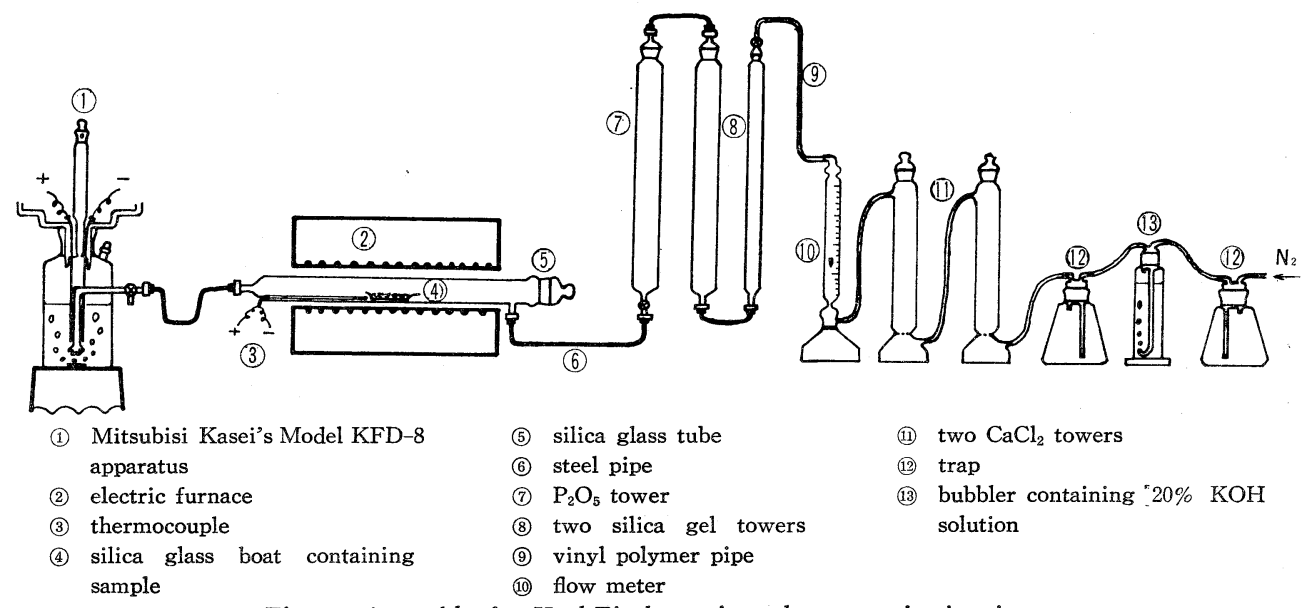

Fig. 3. Assembly for Karl-Fischer micro-electrometric titration.

The determination of moisture in cement was carried out by use of the Mitsubisi Kasei's Model KFD-8 Assembly for Karl Fischer micro-electrometric Titration (see Figure 3). The weighed sample $(2 \sim 3 \mathrm{~g})$ was placed in a combustion boat and inserted into a quartz glass tube furnace which had to preliminarily been dried. When the furnace was heated electrically at a rate of $5^{\circ} \mathrm{C} /$ min. while a slow stream of nitrogen was passed through $(0.15 \mathrm{l} / \mathrm{min}$.), water content held in the sample was released from, absorbed in a methanol -glycol solution and then titrated intermittently with Karl Fischer reagent ( $3 \mathrm{mg} \mathrm{H}_{2} \mathrm{O} / \mathrm{ml}$ ). To obtain a correct value, it was necessary to run through blank test and make a corresponding reduction (i.e., equivalent to $0.1 \sim 0.15 \mathrm{ml}$ of the reagent) from the results of the analysis.

\section{Results and Discussion}

3.1. DTA curves of some commercial portland cements

DTA curves of portland cement No. 01,02 and 03 are shown in Figure 4, in which endothermic peaks are observed at $100^{\circ} \mathrm{C}, 140^{\circ} \mathrm{C}, 270^{\circ} \mathrm{C}$ and $440^{\circ} \mathrm{C}$ respectively. The sample No. 02 has no $270^{\circ} \mathrm{C}$ peak. To make clear the natures of these endothermic effects, the water released from by heating was measured by use of Karl Fischer reagent and the dehydration curves thus obtained were presented in Figure 5 . Up to $200^{\circ} \mathrm{C}$, a continuous dehydra- tion occurs in marked contrast to the endothermic peaks revealed in DTA. The endothermic peaks at about $100^{\circ} \mathrm{C}$ and $140^{\circ} \mathrm{C}$ may reasonably be attributed to removal of adhesive water and dehydration of gypsum respectively. On rising temperature, another dehydration occurs for sample No. 01 or No. 03 somewhat abruptly at $270^{\circ} \sim 300^{\circ} \mathrm{C}$, that is likely to correspond with the $270^{\circ} \mathrm{C}$ peak in Figure 4, but for the sample No. 02 which has no $270^{\circ} \mathrm{C}$ peak, there appears also

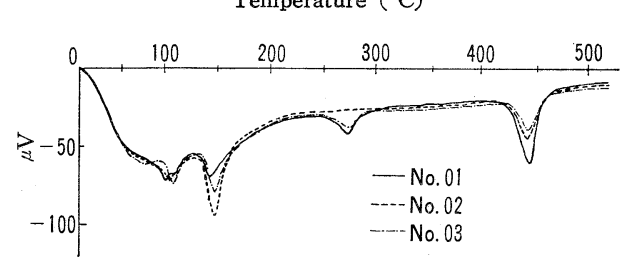

Fig. 4. DTA curves of portland cements, No. 01, 02. 03.

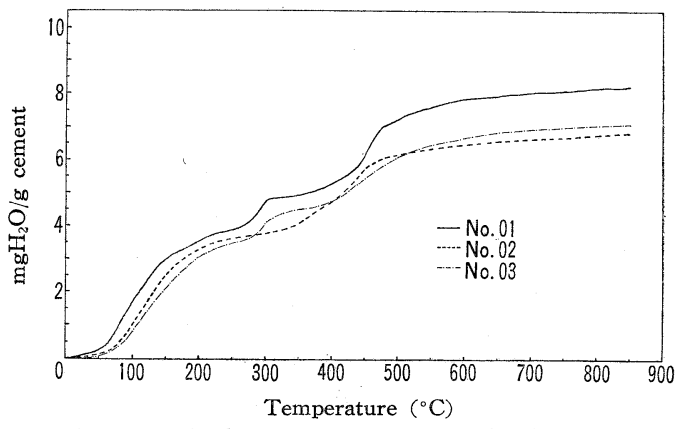

Fig. 5. Dehydration curues of portland cements, No. 01, 02, 03 measured by using KarlFischer reagent (heating rate, $5^{\circ} \mathrm{C} / \mathrm{min}$ ).

no distinct dehydration at $270^{\circ} \sim 300^{\circ} \mathrm{C}$, suggesting that a certain hydrous compound having a dehydration temperature of $270^{\circ} \mathrm{C}$ may present in the sample No. 01 and No. 03. In addition, there occured a distin ct endothermic peak at $440^{\circ} \mathrm{C}$, which might be attributed to the dehydration of cal- cium hydroxide.

3.2. Presence of syngenite $\mathrm{K}_{2} \mathrm{SO}_{4} \cdot \mathrm{CaSO}_{4}$. $\mathrm{H}_{2} \mathbf{O}$

To elucidate the specis of a hydrous compound having a endothermic peak at $270^{\circ} \mathrm{C}$, some works have been done and as a result, this compound could most likely be identified with syngenite on the basis of the following facts.

1) As in the case of cement No. 01 and 03, syngenite has also an intensive endothermic peak 


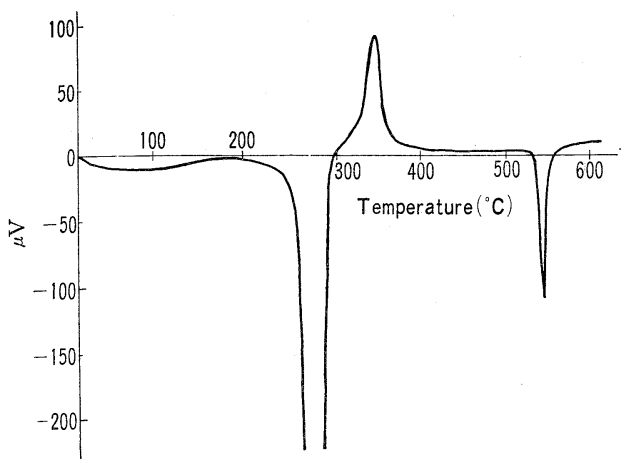

Fig. 6. DTA curve of syngenite.

at $270^{\circ} \mathrm{C}$ owing to the splitting off its hydrated water, the DTA of syngenite being shown in Figure 6. In the figure, an exothermic peak also takes place at $340^{\circ} \mathrm{C}$ and may perhaps be attributed to the rearrangement of some distorted structure set forth by dehydration into $\beta-\mathrm{K}_{2} \mathrm{SO}_{4}$ and $\beta-\mathrm{K}_{2}$ $\mathrm{SO}_{4} \cdot 2 \mathrm{CaSO}_{4}$ and another endothermic peak present at $550^{\circ} \mathrm{C}$ to the transformation of $\beta-\mathrm{K}_{2} \mathrm{SO}_{4}$ thus formed into $\alpha-\mathrm{K}_{2} \mathrm{SO}_{4}$ in accordance with the phase diagram of the system, $\mathrm{K}_{2} \mathrm{SO}_{4}-\mathrm{CaSO}_{4}$.

Syngenite used was prepared as follows, an equimole mixture of potassium sulfate (guaranteed reagent) and natural gypsum (high grade, $\mathrm{H}_{2} \mathrm{O}=$ $20.15 \%$ ) was ground to a fineness enough to pass through 150 mesh sieve, placed in a test tube (20 $\mathrm{mm} \phi \times 200 \mathrm{~mm})$ which was fitted with an air condensor made of glass tube ( $3 \mathrm{~mm}$ in inner diameter) to allow water released from gypsum to roflux, and heated for three hour in an oven at a temperature of $200^{\circ} \mathrm{C}$. The product was identified with syngenite by $\mathrm{X}$-ray diffraction data ${ }^{2)}$, the combined water thereof being measured to be $5.54 \%$ (Cf. theoretical value, $5.49 \%$ ).

2) When the mixture of $\mathrm{K}_{2} \mathrm{SO}_{4}$ and $\mathrm{CaSO}_{4}$. $2 \mathrm{H}_{2} \mathrm{O}$ both in powder states was allowed to stand in the saturated water vapour at any temperature up to about $200^{\circ} \mathrm{C}$, so easily formed syngenite. In Figure 7, DTA curves of the equimolar mixture of $\mathrm{K}_{2} \mathrm{SO}_{4}$ and $\mathrm{CaSO}_{4} \cdot 2 \mathrm{H}_{2} \mathrm{O}$ are shown. The curve a) is for the mixture as mixed and has intensive endothermic peaks at about $140^{\circ} \mathrm{C}$ (dehydration of gypsum) and at $550^{\circ} \mathrm{C}$ (transformation of $\beta$ $\mathrm{K}_{2} \mathrm{SO}_{4}$ to $\left.\alpha-\mathrm{K}_{2} \mathrm{SO}_{4}\right)$ in addition to a weak exothermic peak around $340^{\circ} \mathrm{C}$ (formation of anhydrite $\mathrm{CaSO}_{4}$ III from soluble anhydrite $\mathrm{CaSO}_{4}$ III $)^{3}$. The curve b) is for the mixture that was kept as a thin layer $\left(1 \sim 2 \mathrm{~mm}\right.$ in depth) at $20^{\circ} \mathrm{C}$ overnight in a desiccator containing water to expose it to moist air, and showes the large endothermic peak at $270^{\circ} \mathrm{C}$ marking the presence of syngenite. The curve c) is for the mixture which was aerated as for $b$ ) and then followed by desiccation over $\mathrm{CaCl}_{2}$, hence showes a similar configuration as b)

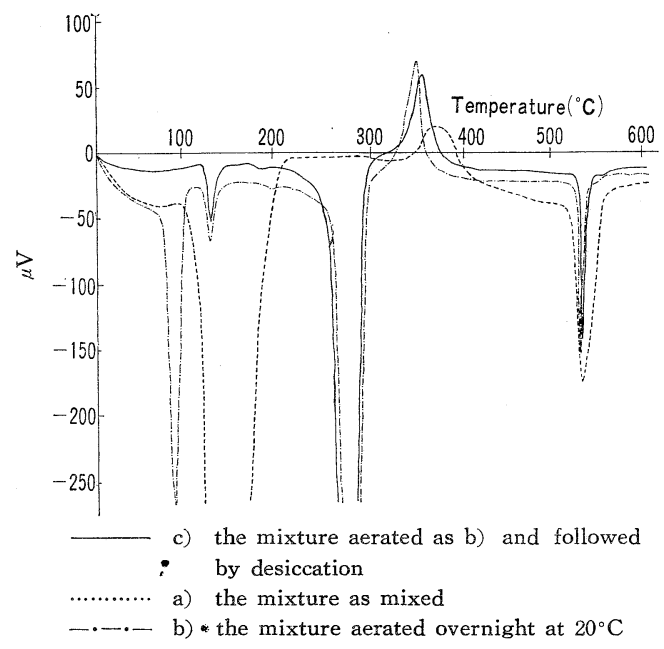

Fig. 7. DTA curves of the mixture of gypsum and potassium sulfate.

büt with a lack of endothermic peak around $100^{\circ} \mathrm{C}$ (removal of free water). In consequence, the presence of some condensed moisture seems to be indispensable to the formation of syngenite from the starting raw mixture as mixed.

3) When the cement clinker No. $1, \mathrm{~K}_{2} \mathrm{O}$ content thereof being $0.62 \%$, was subjected to aeration in the same way as described above with or without incorporation of gypsum, so the sample with gypsum gave the DTA curve exhibiting $270^{\circ} \mathrm{C}$ peak (see Figure 8), suggesting the formation of syngenite therein.

4) As described above, syngenite might be formed in portland cement only when $\mathrm{K}_{2} \mathrm{SO}_{4}$, which is originally present in clinker, would react with gypsum added in a mill under a moist atmospheric condition. In some commercial clinker, $\mathrm{K}_{2} \mathrm{SO}_{4}$ could be detected ${ }^{4), 5)}$ and Suzukawa ${ }^{6}$ ) desc-

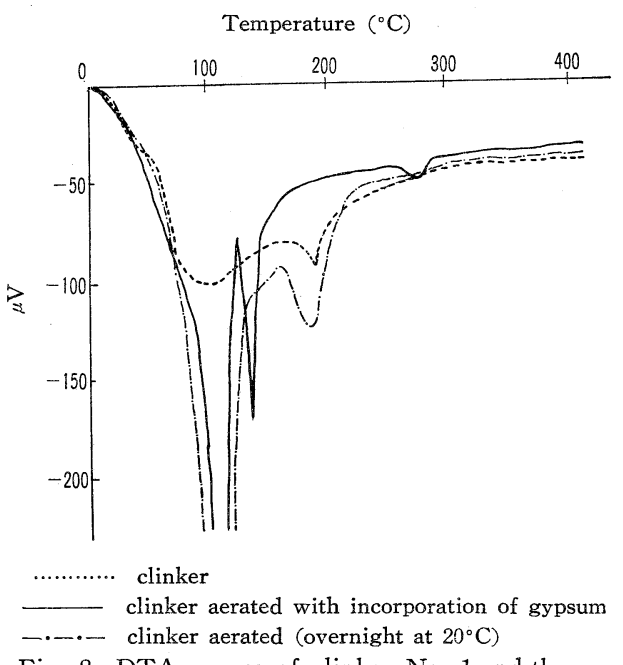

Fig. 8. DTA curves of clinker No. 1 and the one which was aerated with or without incorporation of gypsum. 
ribed that the $\mathrm{SO}_{2}$ from the fuel reacts with $\mathrm{K}_{2} \mathrm{O}$ in preference to $\mathrm{Na}_{2} \mathrm{O}$ in the kiln at a clinkering temperatures. A moist atmospheric condition necessary for formation of syngenite would be realized in some cement mills, as stated by Pollitt ${ }^{7}$. Namely, ball milling generates considerable heat, with consequent possibillities of dehydrating gypsum to the hemihydrate or soluble anhydrite forms. It is therefore usual to cool cement mills by external wetting, and the use of fine water sprays in the last chamber has also been advocated.

These facts are responsible for the possible occurance of syngenite in commercial portland cement. The writers, however, could not confirm directly the presence of the mineral in commercial cement neither under microscope nor by X-ray diffraction, because that syngenite produced by aerating a mixture of $\mathrm{K}_{2} \mathrm{SO}_{4}$ and $\mathrm{CaSO}_{4} \cdot 2 \mathrm{H}_{2} \mathrm{O}$ in powder state at any temperature up to about $200^{\circ} \mathrm{C}$ was liable to be mossy but almost amorphous aggregates in appearance, so under microscope $(\times 400)$ it could hardly be distinguishable from gypsum which had been distorted by entire or partial dehydration. X-ray inspections were also carried out for the sample No. 63 having a large endothermic peak at $270^{\circ} \mathrm{C}$, resulting in, however, that even the strongst diffraction line of syngenite, $2 \theta=31.34^{\circ}, d=2.86 \AA$ could not be detectable.

3.3. Estimation of syngenite and other hydrates in commercial portland cement.

The quantitative estimations of gypsum, syngenite and calcium hydroxide in twelve commercial cements and three pulverized clinkers were tried by measuring peak areas recorded in DTA and the results obtained were shown in Table 2.

Gypsum : In commercial cements, the contents of gypsum, possible amounts of hemihydrate being calculated as dihydrate in this work, varied over the range from zero to 1.7 in weight percent, that is, the ratios of $\mathrm{SO}_{3}$ content as in the form of calcium sulfate dihydrate to the total $\mathrm{SO}_{3}$ were ranging from zero to $46 \%$ with a mean value of $12.6 \%$, indicating that gypsum added to clinker in a mill might be almost dehydrated by the heat generated through ball milling.

Syngenite: The amounts of syngenite were estimated to be from zero to $1.2 \%$, that is, the ratios of $\mathrm{SO}_{3}$ content as in the form of syngenite to the total $\mathrm{SO}_{3}$ were ranging upto $37 \%$ with a mean value of $15.5 \%$. It is noteworthy that many cements contain a perceptible amount of syngenite with a loss of calcium sulfate dihydrate. Though

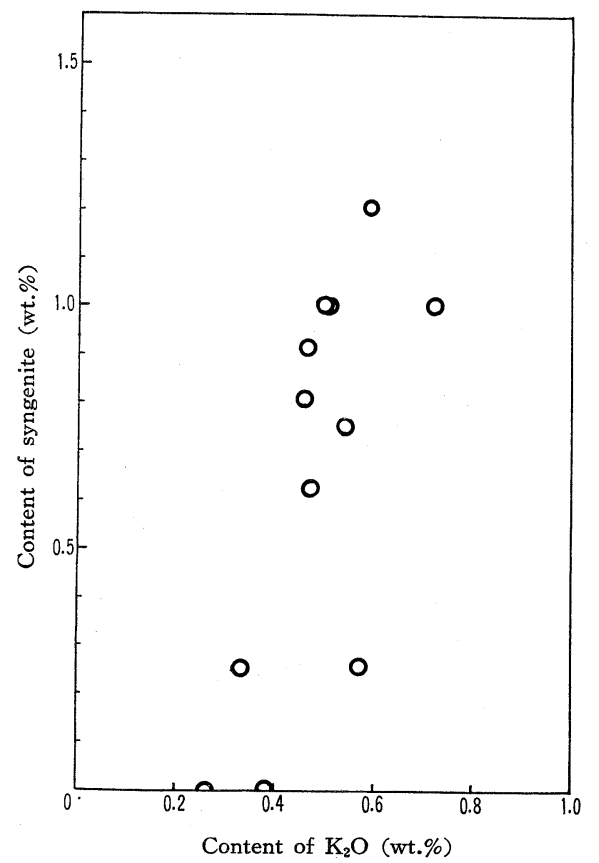

Fig. 9. The contents of syngenite versus that of $\mathrm{K}_{2} \mathrm{O}$ in commercial portland cements.

Table 2. Contents of gypsum, syngenite and calcium hydroxide in commercial portland cements and clinkers.

\begin{tabular}{|c|c|c|c|c|c|c|c|c|}
\hline $\begin{array}{l}\text { Sample } \\
\text { Cement } \\
\text { No. }\end{array}$ & $\begin{array}{c}\mathrm{CaSO}_{4} \cdot 2 \mathrm{H}_{2} \mathrm{O} \\
\text { (I) } \\
(\%)\end{array}$ & $\frac{\mathrm{SO}_{3} \text { as } \mathrm{CaSO}_{4} \cdot 2 \mathrm{H}_{2} \mathrm{O}}{\text { Total } \mathrm{SO}_{3}}$ & $\begin{array}{l}\mathrm{K}_{2} \mathrm{SO}_{4} \cdot \mathrm{CaSO}_{4} \\
-\cdot \mathrm{H}_{2} \mathrm{O} \\
\text { (II) } \\
(\%)\end{array}$ & $\begin{array}{c}\mathrm{SO}_{3} \text { as syngenite } \\
\text { Total } \mathrm{SO}_{3} \\
(\%)\end{array}$ & $\begin{array}{c}\mathrm{Ca}(\mathrm{OH})_{2} \\
\text { (III) } \\
(\%)\end{array}$ & $\frac{\mathrm{CaO} \text { as } \mathrm{Ca}(\mathrm{OH})_{2}}{\text { Total free lime }}$ & $\begin{array}{l}\text { Summation }(\Sigma) \\
\text { of } \mathrm{H}_{2} \mathrm{O} \text { in hyd- } \\
\text { rates } I, I I, \text { III } \\
\quad(\%)\end{array}$ & 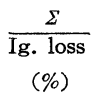 \\
\hline 58 & 0.1 & 2 & 0.8 & 25 & 0.6 & 110 & $0.2_{3}$ & 36 \\
\hline 59 & 1.7 & 49 & 0.0 & 0 & 0.4 & 65 & $0.4_{7}$ & 76 \\
\hline 60 & 0.2 & 6 & 1.0 & 29 & 1.1 & 89 & $0.4_{3}$ & 61 \\
\hline 61 & 0.7 & 15 & 0.9 & 21 & 0.8 & 96 & $0.4_{2}$ & 48 \\
\hline 62 & 0.4 & 12 & 0.3 & 8 & 0.4 & 73 & $0.1_{8}$ & 30 \\
\hline 63 & 0.2 & 6 & 1.2 & 37 & 2.0 & 100 & $0.7_{1}$ & 71 \\
\hline 64 & 0.0 & 0 & 1.0 & 22 & 0.0 & 0 & $0.0_{1}$ & 3 \\
\hline 65 & 0.2 & 7 & 0.3 & 9 & 0.2 & 65 & $0.0_{9}$ & 23 \\
\hline 66 & 0.6 & 15 & 0.0 & 0 & 0.9 & 84 & $0.3_{8}$ & 47 \\
\hline 01 & 0.4 & 9 & 1.0 & 23 & 0.6 & 98 & $0.3_{1}$ & 37 \\
\hline 02 & 0.7 & 18 & 0.0 & 0 & 0.3 & 66 & $0.2_{1}$ & 25 \\
\hline 03 & 0.8 & 15 & 0.6 & 12 & 0.2 & 55 & $0.2_{5}$ & 33 \\
\hline $\begin{array}{l}\text { means } \\
\text { clinker }\end{array}$ & 0.50 & 12.6 & 0.59 & 15.5 & 0.63 & 75.1 & 0.31 & 40.8 \\
\hline $\begin{array}{c}\text { clinker } \\
1\end{array}$ & & & & & & & & \\
\hline 2 & & & & & $\begin{array}{l}0.6 \\
0.4\end{array}$ & 59 & & \\
\hline 3 & & & & & 0.4 & 64 & & \\
\hline
\end{tabular}


it might have been anticipated that an obvious relation between $\mathrm{K}_{2} \mathrm{O}$ contents and the amounts of syngenite would be given for the samples tested, it appears from Figure 9 that this is not usually the case.

Calcium hydroxide: In a fresh clinker free lime is entirely present as calcium oxids, but in a ground cement a considerable portion of the total free lime has been found to present in the hydrated form as calcium hydroxide ${ }^{8)}$. The amounts of $\mathrm{Ca}(\mathrm{OH})_{2}$ varied over the range from zero to $2.0 \%$ by weight of samples, that is, the ratios of $\mathrm{Ca}(\mathrm{OH})_{2}$ content to the total free lime determined by means of the modified alcohol-glycerol method reached to maximum $100 \%$, but with a mean value of $75.1 \%$.

As seen in Table 2, the total amount of water combined to gypsum, syngenite and calcium hydroxide was found to be $0.31 \mathrm{wt} . \%$ on the average and the ratio of which to ignition loss shown in Table 1 be $40.8 \%$, suggesting that as a remainder there would be a considerable amount of adhesive or loosely bound water in addition to carbonate.

\section{Summary}

The species of hydrous materials present in commercial portland cements were investigated by means of DTA and Karl Fischer reagent and as a result, syngenite $\mathrm{K}_{2} \mathrm{SO}_{4} \cdot \mathrm{CaSO}_{4} \cdot \mathrm{H}_{2} \mathrm{O}$, in addition to gypsum and calcium hydroxide, could be detected on several cements tested. Syngenite reveals a distinct endothermic peak at $270^{\circ} \mathrm{C}$ on DTA curve, and from the peak areas measured for twelve commercial cements, the syngenite contents were estimated to be maximum $1.2 \mathrm{wt} . \%$ with a mean value of $0.59 \mathrm{wt} . \%$. The gypsum content was found to be reduced to a mean value of $0.5 \mathrm{wt} . \%$ presumably owing to the dehydration during ball milling, while the ratio of calcium hydroxide to the total free lime reached a value of $75.1 \%$.

\section{Reference}

1) E.M. Barrall, L.B. Rogers, Anal. Chem. 34, 1101 (1962).

2) E. Arúja, Min. Mag. 31, 443-6 (1958); ASTM Card 11-117.

3) L.G. Berg, N.N. Sveshikova, Otdel Khim. Nauk. USSR. 19 (1946), see M. Sekiya, Sekko To Sekkai, No. 64, 89 97 (1963).

4) W.C. Tayler, J. Res. N.B.S. 29439 (1942).

5) A. Glauser, Z K.G. 55 [2] 86-7 (1966).

6) Y. Suzukawa, Z.K.G. 9, 390-6 (1956).

7) H.W.W. Pollitt, "Raw materials and processes for portland cement manufacture", Taylor, The chem. of cement (1) p. 46(1964), Academic Press.

8) For example, F.M. Lea, "The chemistry of cement and concrete" (1956) p. 103, Edward Arnold Ltd, London, and K. Fujii, This Journal 61, 72-6 (1953).

(Received July 3, 1967)

\title{
市販ポルトランドセメント中, Syngenite の存在
}

\author{
藤 井 欽二郎・近 藤 和 吉・真下憲 夫 \\ （工業技術院宋京工業試験所）
}

市販ポルトランド中にどのような種類の含水化合物が

存在するかを, 示差熱分析およびカールフィッシャ一試 薬を用いる水分測定法により検討したところ, 試料セメ ントによっては, 石膏, 水酸化カルシウムのほかに Syngenite $\left(\mathrm{K}_{2} \mathrm{SO}_{4} \cdot \mathrm{CaSO}_{4} \cdot \mathrm{H}_{2} \mathrm{O}\right)$ が生成していること を認めた。 Syngenite は, DTA 曲線において $270^{\circ} \mathrm{C}$ に顕著な吸熱ピークを示し, そのピーク面積からの定量
によると 12 個の試料のうち最大 $1.2 \%$, 平均 $0.59 \%$ の含有量を示した. 2 水塩としての石膏の含有量は, 平 均 $0.5 \%$ にとどまり，拈そらくボールミル 粉砕中に大 部分脱水していること, 打よび全遊離石灰中, 平均 75 \%の酸化カルシウムは $\mathrm{Ca}(\mathrm{OH})_{2}$ の形で存在すること を知った.

(7/31/1967 受付) 